\title{
JUURNAL_RU
}

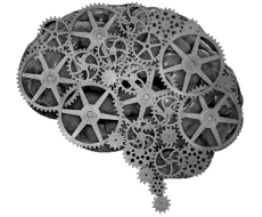

COMPANY GROUP "INTELLEKT"

Солозобова Н.С., Горбачев И.А., Костин К.Б., Пичхидзе С.Я.. СГТУ имени Ю. А. Гагарина

Саратов, Россия

doi: 10.18411/lj2016-5-5-01

\section{Исследование термического нанесения меди на фторопласт-4 и фторсодержащую резину}

В разделе представлены результаты исследований поверхности фторопласта-4 и резины 420-264B/5 после термического нанесения меди.

Целью работы является анализ влияния на свойства поверхности ПТФЭ (фторопласта-4) и фторсодержащей резины нанесенной меди.

Медь на образцы наносилась при разности потенциалов 2,5 кВ. Скорость напыления 10-30 нм/с. РФА показал образование $\mathrm{CuF} 2$, что можно объяснить реакциями дефторирования полимерной цепи ПТФЭ и СКФ-264В/5 [1,2]. ИКанализ подтверждают образование ненасыщенных связей.

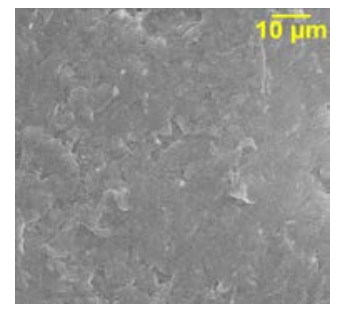

a

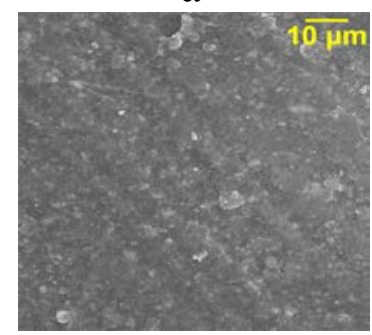

$\Gamma$

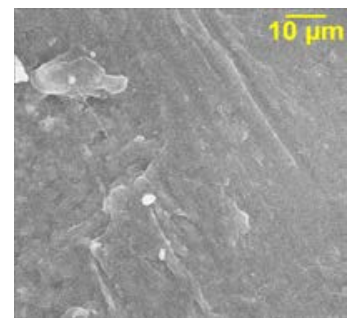

6

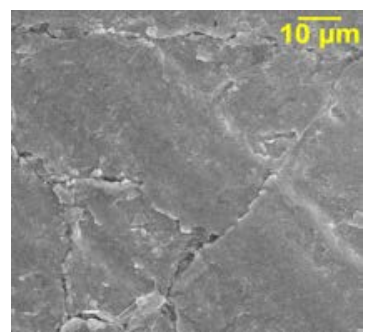

Д

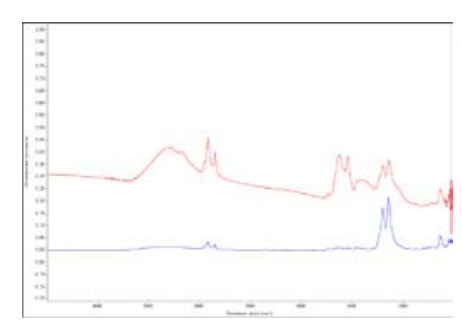

B

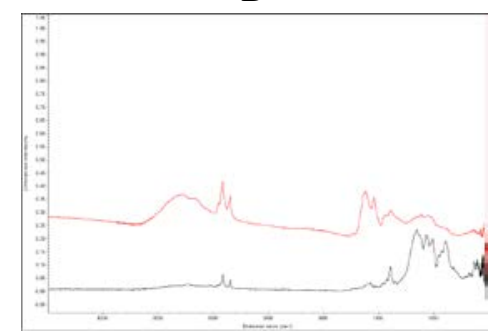

$\mathrm{e}$

Рис. 1. Данные РЭМ при увеличении 2500x: a ПТФЭ, б - Си на ПТФЭ, г - резина, д - Си на резине

Рис. 2. ИКС НПВО: в - Си на ПТФЭ (верх), ПТФЭ (низ), е - Cu на резине (верх), резина (низ) 


\section{Литература:}

1. Шумилин А.И., Гринёв В.С., Фёдоров Е.Е., Таганова В.А., Телегин С.В., Пичхидзе С.Я. Адгезионная прочность при расслоении фторсодержащей резины и ПТФЭ. Пластические массы. 2014. № 3-4. С. 35-38.

2. Байбара В.С., Шумилин А.И., Таганова В.А., Пичхидзе С.Я. Поверхность фторопласта-4 при термическом нанесении меди. Конференция Элпит-2015. Тольятти: ТГУ. 2015. - 3c. 